$1-29-2016$

\title{
Rethinking Secularism in Europe
}

Follow this and additional works at: http:/ / digitalcommons.osgoode.yorku.ca/ transnationalism_series

\section{Recommended Citation}

"Rethinking Secularism in Europe" (2016). Legal Philosophy between State and Transnationalism Seminar Series. 44. http://digitalcommons.osgoode.yorku.ca/transnationalism_series/44

This Article is brought to you for free and open access by the Seminars at Osgoode Digital Commons. It has been accepted for inclusion in Legal Philosophy between State and Transnationalism Seminar Series by an authorized administrator of Osgoode Digital Commons. 


\title{
Rethinking Secularism in Europe
}

\author{
Lorenzo Zucca
}

The paper argues that secularism in Europe needs to be fundamentally reconsidered. Everywhere European secular states face a double threat: on one hand fundamentalist religion, on the other negative secularism. Firstly, the paper will explain what is negative secularism and why it is a problem rather than an asset. It will then elaborate a new conception of positive secularism that can be understood either as a political or as an ethical project. Either way, the point of positive secularism is to distance itself from religion in order to embrace diversity of all types, religious and non-religious. Political secularism, however, relies on an elusive hope of reaching overlapping consensus between religious and non-religious people. Ethical secularism aims instead to protect diversity by promoting the establishment of a marketplace of religions, which acknowledges a public role for religion while regulating it. The marketplace of religions promotes religious pluralism and helps to iron out the different treatments between religions. Ethical secularism aims to be a worldview of worldviews that creates the preconditions for all religious and non-religious people to live well together.

Intro

A spectre is haunting Europe - the spectre of secularism. All the powers of old Europe have entered into a holy alliance to exorcise this spectre: Pope and Putin, Merkel and Hollande, French intellectuals and the European Court of Human Rights. ${ }^{1}$ Everywhere the secular state is under threat. One obvious threat comes from the revival of religion in Europe, and in particular its extremist manifestation. ${ }^{2}$ The tragedy of Charlie Hebdo shows the cleavage between European states and extremist minorities. A second threat comes from the spread of negative secularism: religion is regarded as an enemy of the secular state. This kind of secularism is historically dated, legally inapplicable and politically inadequate. The view I'm rejecting is exemplified by the standard French position of ideological laïcité, which gave rise to the recent statute banning burquas in public streets. This ideological interpretation of laïcité suggests that religion can only be free as a purely private and inward looking practice: instead of understanding religion, ideological forms of secularism attempt to deny its social role and meaning and confine religious practices in private spaces.

Europe needs to rethink secularism and freedom of religion fundamentally. To be sure, freedom of religion in a secular age is a paradox: why single out for special

\footnotetext{
${ }^{1}$ This is adapted from Karl Marx's Manifesto.

${ }^{2}$ See for example, Susanna Mancini and Michel Rosenfeld (eds), Constitutional Secularism in an Age of Religious Revival, Oxford: OUP, 2014.
} 
protection something that is no longer special? Courts are central players in this paradox. They do decide when a claim is deep enough to be a claim of conscience. ${ }^{3}$ They are asked to discriminate between what is religion and what is not. ${ }^{4}$ The second paradox flows from the first; in a secular age, religion does not have a stable definition; as a result secularism is much harder to define: it just turns out to be a denial of whatever happens to be identified as religion. But since no legal definition of religion is neutral, then the denial of an ideological position is also an ideological position. This is what characterizes negative secularism, namely the view that the secular state should focus on the denial of religion's place in the public sphere.

I suggest instead that secularism should be thought of as a positive attitude towards all forms of diversity in the society, including religious views. I call this positive secularism; its point is not to deny religion's place in the public sphere, but to promote diversity of worldviews. ${ }^{5}$

European Courts, I shall argue, have a special responsibility: to promote diversity of worldviews and pluralism throughout Europe. Courts have an incredibly expansive role to play here. They define religion when they are asked to protect freedom of religion. And negatively, they also define secularism. Moreover they have to manage the attitude of political institutions towards religion. Finally, they have to make sure that diversity does not threaten political unity. For the moment, they have abdicated their responsibility: they oscillate between two sides that can be illustrated through two recent landmark cases of the European Court of Human Rights (ECtHR): Lautsi v Italy $^{6}$ and SAS v France. ${ }^{7}$ In the first case, the crucifix is held to be a passive symbol and therefore acceptable in the public classroom. In the second case, the full-face veil is considered as a bar to living together and therefore prohibited as a form of private clothing. Such a glaring double standard points to the existence of in-built biases in favor of majority religions and against minority beliefs. European secular states do not know how to cope with religious diversity. Their secularism oscillates between a

\footnotetext{
3 Taylor and McLure, Secularism and Freedom of Conscience, Harvard University Press (2011).

${ }^{4}$ See Lorenzo Zucca, A Marriage Made in Heaven? The relationship between religious pluralism and secularism, in Ferran Requejo and Camil Ungureanu (eds), Democracy, Law and Religious Pluralism in Europe: Secularism and Post-Secularism, Ashgate (2014).

${ }^{5}$ A similar distinction is offered by Charles Taylor 'How to define Secularism,' in Alfred Stepan and Charles Taylor (eds), Boundaries of Toleration, Columbia University Press (2014).

${ }^{6}$ Lautsi v. Italy, no. 30814/06, 18 March 2011.

${ }^{7}$ S.A.S v France. no. 43835/11, 1 July 2014.
} 
negative attitude towards minorities and a positive attitude towards traditional majorities.

European Courts have to be bolder: in order to address the damning problem of the double standard, the point is to move beyond the negative conception of secularism that they attack. In section 1, I will illustrate the ways in which the ECtHR is stuck with a negative conception of secularism. To go beyond it one needs to develop a new conception of secularism, which I call positive secularism. Section 2 will present two possible variants of positive secularism and it will illustrate how positive secularism could inform the practice of the ECtHR so as to nudge European states into being secular in a way that is compatible with religious pluralism.

\section{Negative Secularism}

Negative secularism is defined in opposition to religion. It carves out a domain for religion and one for secular politics. It was simple to understand what secularism and its point were when European states were culturally and religiously homogeneous. Christian religion and secularism were the two sides of the same coin. Christianity was not contested as a metaphysical doctrine or as an ethical standpoint. This was Europe after the Treaties of Westphalia: religious homogeneity was engineered in order to avoid conflicts between Catholics and Protestants. Ejus regio, cujus religio (to each kingdom its own religion) was the formula behind the birth of European nation states. From this viewpoint, secularism was just a compromise between each state and its own religious majority. ${ }^{8}$ Today's Europe has changed beyond recognition since 1648. Three centuries later, and after two world wars, the European system of nation states had to be re-considered. The UDHR, which inspired the ECHR, and the Treaty of Rome that lays the foundation of the EU, regard human rights as the necessary limitation of state sovereignty. European human rights protect diversity of worldviews over homogeneity and European Courts have to act accordingly. ${ }^{9}$ Negative secularism was formulated in a historical context where the secular state had to free itself from one dominant religion: the French State had to distance itself from

\footnotetext{
${ }^{8}$ Lorenzo Zucca, A Secular Europe. Law and Religion in the European Constitutional Landscape, OUP (2012).

${ }^{9}$ Eva Brems (ed.), Diversity and European Human Rights. Rewriting Judgements of the ECHR, CUP (2015).
} 
the interference of the Catholic Church and did so with the statute of 1905, which formulated the legal principle of laicite'. ${ }^{10}$ Today, laicite' is interpreted as denying religion any place in the public sphere, and securing its liberty only in the private sphere. Such interpretation is an ideological distortion of the principle of legal laicite which simply requested the separation between church and state. In what follows I criticize the position of the ECtHR for embracing a negative idea of secularism that portrays it in turn as a private conviction (a), as an ideology (b) or as a biased stance against minority religions (c). These three mistakes are part of a negative project of secularism (d) that needs to be abandoned.

a. Secularism as private conviction

Secularism is not à la page in Strasbourg. In the Lautsi saga, the ECtHR had to decide whether Italy was violating the right of parents to have their children educated in a way that is compatible with their convictions. Mrs Lautsi complained in particular that the presence of the crucifix interfered with the secular education expected in a state school.

In the last resort, the Grand Chamber of the ECtHR concluded that Italy has the freedom to decide whether to hang a crucifix in public school's classrooms without infringing the right of parents to have their children educated according to their own religious or philosophical convictions.

At the chamber level, the decision went in the opposite direction. Secularism featured prominently and determined the outcome of the case in favor of the applicants, the Lautsi family: the court decided that the state has an obligation of neutrality in light of its secular nature. As a consequence, the wall of the classroom had to be blank, since the presence of any symbol would breach the state commitment to neutrality on one hand, and the parents' right to educate their children according to their own religious or philosophical convictions. The Chamber presented secularism as Mrs Lautsi's philosophical conviction. The idea needs to be criticized as it portrays secularism as radically subjective: one of the many beliefs that can be held by people. This will turn

10 Olivier Roy, Secularism confronts Islam, Columbia University Press (2009). 
out to be a major conceptual and strategic mistake. It is a conceptual mistake because it confuses the secular nature of the state with individual preferences of the parents. Secularism as a conviction is at best a by-product of state secularism; it should not be boxed into the language of art. 2 protocol 1, which reads as follows: "No person shall be denied the right to education. In the exercise of any functions which it assumes in relation to education and teaching, the state shall respect the rights of parents to ensure such education and teaching in conformity with their own religious and philosophical convictions." The court links parental secular convictions to secularism, thereby creating a basic confusion that still lingers on: the idea is that secularism could be considered as one of the many possible individual convictions, rather than the most important political project that Europe has embraced since the end of the wars of religions. Secularism in European constitutional history is a political project according to which the state should be run independently from the dominant religion in a given society. To present it instead as a philosophical conviction of the parents leads people to believe that secularism is an optional way of leading the state's business. ${ }^{11}$ There is not a single European state that is not secular to a greater or lesser extent. The converse of being a secular state would amount to being a theocratic state.

The Chamber's judgment makes a strategic mistake as well: by insisting that the wall of the classroom should respect parents' convictions, the court is preparing the scene for the perfect storm. Why would the secular convictions of some parents be preferable over the religious convictions of other parents? Put this way, it becomes impossible to defend state neutrality. The state has no ability to choose between two convictions neutrally. It is either one or the other. The problem here is that the state's default secular position as a guarantee of all convictions has been undermined by the move of the court that unwittingly put religious convictions and secular convictions on a par, as if the two were mutually exclusive and addressed the same set of beliefs. Herein lies one of the great weaknesses of negative secularism: it tends to simplify reality into two polar opposite. By the same token, it equalizes them. Religious convictions and secular convictions have the same value in the eye of the court.

\footnotetext{
${ }^{11}$ Even theocracies cannot do away with a minimum commitment to secularism.
} 
The opponents of secularism raised their glasses. The Catholic Church, together with Russia, and other intervening states, banqueted on the corpse of secularism. The political battle begun and it aimed to assert the Christian roots of the European project. Lautsi's Chamber decision gave the opportunity to religious people to call for more representation of religion at the national and supranational level. The Grand Chamber of the ECtHR tried to limit the damage but the faux pas had already been taken. To present secularism as an individual conviction empowered religious convictions to claim equal treatment before the law and in the court. The alleged neutrality of the secular state had been compromised in the quest of protecting the secular views of the Lautsi family.

Some of the concurring opinions -in particular Judge Bonello's - went a long way in delegitimizing secularism as the defining trait of European states and of Europe as a whole. In his colorful concurring opinion, Bonello claims that: "in Europe, secularism is optional, freedom of religion is not." 12 This is a highly controversial claim. As pointed out, the converse of secularism is theocracy. It is hard to find examples of theocratic societies where freedom of religion is upheld. We can try to be charitable with Bonello: he may be suggesting that secularism is a defining trait of constitutional democracies, but not of an international system of human rights. However, even that claim is highly controversial. There is a minimal sense in which an international system of human rights is necessarily secular in so far that it has to refrain from taking the viewpoint of any given religion so as to be capable to protect all religions equally.

So the question is not whether secularism is optional or not; the question is which secularism is best suited to an international system of human rights. Moreover, it is hard to imagine how freedom of religion could be protected in a non-secular political space. Let us imagine - this time it is not hard to do - a state that is run on religious precepts taken from one religion. In this case, the majority's religion does not need freedom, since it has power. Other religions in this non-secular framework will enjoy freedom only to the extent that the majority's religion is willing to give it to them as a concession that can always be withdrawn. It follows that, contrary to what Bonello

\footnotetext{
${ }^{12}$ Lautsi v. Italy, no. 30814/06, 18 March 2011, paragraph 25, p.40.
} 
claims, freedom of religion as a human right can only truly exist in a secular framework that does not discriminate between any religion. Bonello's mistake is to believe that freedom of religion and secularism can be easily detached one from another. Interestingly, Bonello also acknowledges that: "I believe anyone could persuasively try to argue that the presence of the crucifix in Italian State schools might possibly offend the doctrine of secularism and that of the separation between Church and State." At this point, the opinion of Bonello has changed tone: $\mathrm{He}$ recognizes that secularism is not an option. But he would like to suggest that the task of the court does not include the review of a measure incompatible with the principle of secularism. The court's job, according to Bonello, is simply to protect the right to freedom of religion of the parents. Again, there is a distortion taking place here: firstly, the Lautsi family is not complaining about their right to freedom of religion, but about their right to have an education for their children in a non-religious environment. The question is whether the crucifix, which is a religious symbol, gives the environment a religious connotation. To answer this question one has to engage with the boundary that lies between a religious and a secular environment. The Grand Chamber, by deciding that the Italy is free to keep the crucifix in Italian state school, is implicitly asserting that the presence of that symbol is compatible with the principle that state school should by law be secular spaces.

\section{b. Secularism as Ideology}

Part of the blame for being in this predicament should be laid at the door of secularism as a political project. Secularism is the product of historical events that pitted Church against the State and produced a series of ready-made doctrines to cope with such a problem: the most famous, and the most controversial, is the doctrine of the separation between Church and State. The wall of separation has been exposed as a deficient metaphor in the US, Europe and India. ${ }^{13}$ When we look at the reality of the relation between Church and State, it can hardly be described as a form of mutual segregation. Religious symbols, practices and beliefs enter the political realm as much as state laws enter the religious one.

\footnotetext{
${ }^{13}$ L. Sager and C. Eisgruber, Religious Freedom and the Constitution, Cambridge, Mass: HUP (2010); Rajeev Bhargava, "Should Europe learn from Indian secularism?," available at http://www.indiaseminar.com/2011/621/621_rajeev_bhargava.htm.
} 
Originally, secularism was thought of as a good faith attempt to resolve a conflict; the idea was to allow the state to free itself from the bonds of one religion (or of many religions) in order to be the state of all the citizens. In order to treat everyone equally, the state had to be blind to religious symbols, and deaf vis-à-vis religious beliefs. One can readily see, however, how good intentions can be transformed in evil plans. From a legal-constitutional project, secularism was turned into a social ideology according to which religion should be relegated to the private sphere. This is what happened in France with the Loi 1905 on laïcité: the statute did not originally claim that religion should be silenced in the public sphere. It simply attended to draw a line between church and state. But on time it was taken to represent a negative indictment of religion's presence in public.

In a separate concurring opinion, Judge Power stubbed secularism in its ideological back: "To my mind, the Chamber Judgment was striking in its failure to recognize that secularism (which was the applicant's preferred belief or world view) was, in itself, one ideology among others." ${ }^{14}$ I believe instead that Judge Power's concurring opinion is striking in its failure to recognize that secularism is not only another ideology, but also the backbone of any modern state. I readily recognize that that backbone has been used with negative effects upon religion, and I also recognize that it is high time to re-think secularism for an entirely new world. The historical context has changed beyond recognition, and the chief aim of the secular state is not to deny religion a place in the public sphere as the French conception of laicite does. ${ }^{15}$ Rather, the secular state has the task of protecting religious and non-religious ways of thinking as part of a plural and diverse society. To do so the secular state needs a framework, which guarantees that no particular view can be imposed over other people.

Secularism does not have to be an ideological stance against religion. It is fair to say that that might have been the interpretation of Mrs Lautsi, but that should not be the way in which the state interprets secularism. If and when the state interprets it that way, it is fair to criticize the state for not giving religion its due, and for unduly

\footnotetext{
${ }^{14}$ Lautsi v. Italy, no. 30814/06, 18 March 2011. pp. 44-45.

15 Olivier Roy, Secularism confronts Islam, Columbia University Press, (2009).
} 
burdening it. A different, possible, interpretation of secularism brings us back to secularism as a collective political project to guarantee the co-existence of different beliefs and ideologies. Judge Power chastised the Chamber for elevating secularist ideology over all other ideologies. But my point is that secularism properly conceived is not at all an ideology; it is the necessary pre-condition for beliefs and ideologies to co-exist in the same space. Secularism should be conceived of as a normative requirement to respect any kind of diversity of religious and non-religious type. It does not merely amount to a position arrived at through (overlapping) consensus amongst people who want to live in the same space. In Europe, such consensus would be hard to formulate against the background of a set of political societies that have been based on homogeneity rather than diversity.

Judge Power would like to salvage neutrality from the damning criticisms issued against the Chamber's decision. She attempted to do so by severing neutrality from secularism, and by suggesting instead that neutrality is better served by a general commitment to pluralism: "Neutrality requires a pluralist approach on the part of the State, not a secularist one. It encourages respect for all world views rather than a preference for one." 16 It is very difficult to conceive of a non-secular state that would promote respect for all religions. The European experience teaches us precisely that when one religious view is in charge, other religious views can at best expect toleration. In the same vein, it is hard to imagine how a non-secular state could promote pluralism without having to deny the primacy of the religious views in which it believes. If we were to believe the Court, secularism is just another ideology. It is a partial view of the world that is on a par with many other political ideologies, including religious views. It is undeniable that French secularism based on the Loi of 1995 was firstly conceived of as a legal separation between church and state but then became an ideological stance that relegated religion to the realm of private life. However, the fact that laicite were transformed into an ideological stance, does not mean that secularism is an ideology as any other. If we were to replace secularism with any other religious ideology, the result would not be the automatic protection of religious pluralism. The link between pluralism and secularism is hard to deny: secularism may be an ideology, but it is crucially an ideology that promotes diversity

\footnotetext{
${ }^{16}$ Lautsi v. Italy, no. 30814/06, 18 March 2011, p. 44.
} 
above homogeneity. This is not true of other ideologies, in particular of religious ideologies who would be happy to maintain a privileged status for one religion.

\section{c. Secularism and Islamophobia}

The paradoxical consequence of Lautsi's decision is Strasbourg's neutrality vis-à-vis national arrangements that are paradigm cases of negative secularism: France and Turkey spring to mind. In which way is the ECtHR protecting freedom of religion in the case of SAS v France? France decides to criminalize the wearing of the full-face veil in Public Street and the court decides that the ban is compatible with freedom. ${ }^{17}$ What could justify such a ban? The court suggests that the individual right to freedom of religion can be limited on the grounds of the rights of others. ${ }^{18}$ But in this case, what are the rights of others that are at stake? Why should I have a right against someone who decides to cover her face? I may want to wear a carnival mask on a daily basis, would that violate the rights of others? There is very little that can fit the bill: there is no tangible right of others that can be singled out. Compare with Lautsi: the readily identifiable 'right of parents to ensure such education and teaching in conformity with their own religious and philosophical convictions (art. 2 protocol 1)' is treated as not having been infringed because Mrs Lautsi cannot prove the impact of the presence of the crucifix on her children. In SAS, the court argues that the wearing of the full veil on public streets has a sizable impact on the French republican principle of living together.

The court attempted to give some content by subscribing to the principle evoked by the French government: living together. Wearing the full-face veil, according to the French government would prevent people from forming the necessary bonds in a society. While it may be correct that a full-face veil creates an obstacle to immediate socialization, it is unclear why it would violate the rights of others. Living together does not provide the necessary content. More importantly, it is impossible to understand why secularism in Lautsi is presented as an abstract doctrine that has no connection with the rights of the convention, while living together is accepted as a meaningful position that gives content to the rights of others. There is a strong 
presumption here that the court uses abstract principles to suit its political preferences. In the case of SAS, living together rings as a pretext to impose the views of the majority as to what symbols and clothing are considered to be conducive to stronger social bonds. If anything the principle of living together should encourage more understanding of alternative ways of life -here we are talking of two thousand women in the whole country-rather than aggressively single out those people who are deemed to be inacceptable.

There you can see the germ of the French legislation banning the full-face veil in public streets. A confusion that lingers on in this debate has to do with the distinction between private and public. Is walking down the street a public act? More importantly, to insist on the idea that religion is free in the private realm, and that people should strip themselves of religious clothes and symbols create an extra burden for religious people when compared to non-religious people. In other words, non-religious people are the model citizens while religious people have to behave as if they were non-religious when they step in the public sphere. Another source of doubt comes from the sociological analysis of the full-face veil in France. The number of women wearing it is extremely limited: two thousand women out of a minority of four million people. ${ }^{19}$ It is therefore possible to carry out interviews with a great number of them and learn that their motivation is largely individual and even goes against the grain of the community that opposes such practices.

France asks everyone not to take offense if religion is ridiculed. But then it takes offence if someone wears its own religious symbols while walking down the street. This is another double standard that needs to be unraveled and discussed. In neither of the case, offense seems to be sufficient to regulate the relevant behavior. Behind the benign face of neutrality, hides the dark face of double standard; Christian religion can be embraced by a secular state as a form of tradition. But when other religious traditions claim freedom of religion, they are silenced in the name of the requirement of living together. The irony (and the deep sadness) lies in the fact that Lautsi had allowed the display of the majority's religious symbol in a classroom, pointing out that secularism is just an individual conviction like any other. In SAS a minority's

\footnotetext{
${ }^{19}$ Eva Brems, 'The experience of face veil wearers in Europe and the law,' in Eva Brems (ed.), Diversity and European Human Rights. Rewriting Judgements of the ECHR, CUP, (2015).
} 
religious symbol in the public street is prohibited, on the grounds that it is incompatible with an ideological understanding of French secularism. The morale is that freedom of religion amounts to the protection of whatever the majority happens to believe, be it religious or secular ideology. It is high time to rethink secularism and freedom of religion in a way that truly promotes living together -minority and majority alike.

\section{d. Secularism as a negative project}

Secularism is associated with disenchantment: from a world full of religious meaning, we come to a world emptied of its spiritual and magical content. ${ }^{20}$ Some feel nostalgia for a world that has disappeared and that will not come back. ${ }^{21}$ Secularism is not so much to blame here, but it is regarded as the empty alternative that has come to the scene. It does not make up for the loss incurred. It does not propose anything. It lacks the vision or the teleology that was provided for by religion. How can we possibly subscribe to a negative project that does not offer any substantive value to guide the society, a view that requires taking a negative stance towards religion?

The first step in that quest is to separate the concept of secularism from the concept of religion. If the two are too tightly linked, then secularism can only be understood as the denial of religion. There are many problems with such a negative approach, but the most daunting lies in the fact that there is no definition of religion in the first place. Thus, it is also impossible to define secularism; if anything it will be identified with whatever opposes religious beliefs and practices. But what if some of those religious beliefs and practices are part and parcel of the constitution of a society? To oppose them, would amount to oppose the very identity of a society. Does secularism amount to the denial that some political societies define themselves in relation to religious beliefs or practices?

Needless to say, it would be detrimental for secularism to do so. In fact, it seems unavoidable to detach the concept of secularism from that of religion. In particular, it is impossible to take theology as a starting point for a definition of religion. More

\footnotetext{
${ }^{20}$ C. Taylor, 'Disenchantment- Re-enchantment', in G. Levine, The Joy of Secularism, PUP (2012).

${ }^{21}$ Taylor is amongst those who are nostalgic of a Christian past, regarded as a more meaningful past.
} 
precisely any type of monotheistic religion that comes with a theological apparatus has to be put aside in order to make space for non-monotheistic concepts of religion. Religion cannot be defined in relation to the presence of one God. It is equally clear that there is no secular definition of religion from an external viewpoint to religion: endless attempts have been attempted without success. ${ }^{22}$ Religion defines itself from within. The problem arises when religion needs the official stamp of the state in order to benefit from a number of benefits or exemptions.

It is interesting to note that judges are now being forced to reconsider their narrow assumptions as to what qualifies as religious. Once the monotheistic definition is swept under the carpet, it is hard to think of what could replace it to provide a stable yardstick with which to draw the boundary between religion and non-religion: that is to say, for many, between religion and the secular. It seems as if judges are slowly moving towards a more empirical approach, which takes into account actual social and cultural practices. ${ }^{23}$ The challenge for all judges is to come up with a legal definition of religion that is truly reflective of religious diversity in Europe. This is an Herculean task that will transform in a Sisyphus struggle. A secular court cannot define religion because it is required to refrain from engaging with internal theological arguments. The seeming impasse can be dealt with by accepting that courts cannot provide a bright line rule between religion and non-religion. At best they can gather evidence from all parties involved and attempt a case-by-case approach open to revision. Also, courts can

THE ECtHR attaches a great importance to liberal neutrality, while being very deferential to the way in which nation states defines it. In those two landmark cases, the court approves of the status quo: France is neutral when banning burqua on public streets; Italy is neutral when defending the crucifix in public schools. Today the status quo is particularly problematic given the deep change of social context. The role of the ECtHR should be more positive: to question nation states on their commitments rather than subscribe to, and rubber-stamp, them. The court's position vis-à-vis

\footnotetext{
22 See for example Brian Leiter, Why Tolerate Religion?, Princeton University Press (2012).

${ }^{23}$ Lorenzo Zucca, 'A Marriage Made in Heaven? The relationship between religious pluralism and secularism', in Ferran Requejo and Camil Ungureanu (eds), Democracy, Law and Religious Pluralism in Europe: Secularism and Post-Secularism, Ashgate (2014).
} 
negative secularism can be understood, but this does not mean that secularism is altogether incapable to provide a sound basis for the interpretation of human rights.

\section{Positive Secularism}

Positive secularism is not defined in opposition to religion. ${ }^{24}$ It is not about separation between church and state, nor is it about privatization of religion. Crucially it does not attempt to define religion from the standpoint of secular reason. Positive secularism is about the protection and promotion of diversity of worldviews. There are two ways of doing so: Charles Taylor's political secularism suggests that liberal democracies have to cope with diversity by seeking to uphold consensus wherever possible; the other option, which I defend here, is by showing that diversity is ethically superior over homogeneity. My account can be called ethical secularism, and can be contrasted to Taylor's political secularism.

The two accounts have nevertheless many points in common. ${ }^{25}$ Neither Taylor's, nor my account, define secularism in opposition to religion. But Taylor's account of secularism is political in the Rawlsian sense: it works along the lines of public reason, and defines it as that set of reasons that would be followed by reasonable people. ${ }^{26}$ My account starts from the acknowledgement that even reasonable people have inbuilt biases that are part of their beliefs and practices. The double standard applied by the ECtHR, exemplified by the opposite treatment of Christian and Islamic symbols, is an example of such bias and it affects the decisions of allegedly reasonable judges and all other policy makers. It is not possible to ask the state, or its officials, to be neutral between their own biases and other religious views. The first difference between those two positive accounts is a practical concern: how does one remove the bias? Taylor's political account would trust the state to be a neutral arbiter between reasons that are public and reasons that are not. I believe instead that the state cannot be neutral at least as long as it has not freed itself from those in-built biases. Firstly it

\footnotetext{
${ }^{24}$ C. Taylor, 'How to define Secularism,' in Alfred Stepan and Charles Taylor (eds), Boundaries of Toleration, Columbia University Press (2014).

${ }^{25}$ Perhaps they even share the same intentions, but they differ as to the means necessary to achieve them.

${ }^{26}$ C. Taylor, 'How to define Secularism,' in Alfred Stepan and Charles Taylor (eds), Boundaries of Toleration, Columbia University Press (2014), p. 61.
} 
has to unravel the buried biases and tackle the negative emotional reactions to diversity. Then it has to reformulate its own secular commitments. In the process, the secular state is likely to realize that it can hardly rely on a political account but has to provide an ethical account of positive secularism. Thus, my account of positive secularism is ethical in that it claims to be normatively superior to any other alternative on comprehensive grounds as opposed to Rawls' and Taylor's framework which is supposed to be grounded on overlapping consensus that does not appeal to any comprehensive views.

\section{a. Political secularism}

Taylor's account of political secularism is divorced from his account of a secular age. ${ }^{27}$ Taylor shows that the secular age has ushered in a great diversity of individual conceptions of the good that cannot be squared one with another. ${ }^{28}$ As a result, there are various secular dilemmas that arise in modern society. It is therefore puzzling that Taylor advocates state neutrality as the tool with which the state should deal with those dilemmas: what would it mean to be neutral between two competing values or goods that clash one against another? Taylor's position seems to be oscillating between taking neutrality as a regulative principle and taking it as one of the values to be balanced. For example, he claims on one hand that: "the point of state neutrality is precisely to avoid favoring or disfavoring not just religious positions but any basic position, religious or non-religious. We can't favor Christianity over Islam, but also religion over against nonbelief in religion or vice versa." ${ }^{, 2}$ But on the other he criticizes French laïcité for being fixated on one single principle: "the dilemma and its resolution remain hidden under the illusion that there is only one principle here, say, laïcité and its corollary of the neutrality of public institutions or spaces." ${ }^{, 30}$ The first quote treats neutrality as a regulative principle, while the second quote treats it one principle amongst others. This illustrates the point that Taylor oscillates between those two conceptions of neutrality without taking a clear position.

\footnotetext{
${ }^{27}$ Compare C. Taylor, A secular Age, HUP, (2007) with J. Maclure and C. Taylor, Secularism and Freedom of Conscience, HUP (2011).

${ }^{28}$ Charles Taylor, A Secular Age, HUP, 2007.

${ }^{29}$ C. Taylor, 'How to define Secularism,' in Alfred Stepan and Charles Taylor (eds), Boundaries of Toleration, Columbia University Press (2014), 60-61.

${ }^{30}$ C. Taylor, 'How to define Secularism,' in Alfred Stepan and Charles Taylor (eds), Boundaries of Toleration, Columbia University Press (2014), 60.
} 
Taylor bemoans the disappearance of a comprehensive Christian view of the world: he displays nostalgia towards an enchanted world that has disappeared, an age that has gone and that will not come back: the age of religious monism. Taylor is clear that western secularism has been so far obsessed by the quest to divide religion from power through a single simple-minded formula such as the wall of separation. ${ }^{31}$ But things are more complex than that, Taylor insists, and this is particularly so in plural societies where the point of secularism should be completely redefined: it should deal with religious and metaphysical diversity of all kind; it should not focus on the control of religion as orthodox secularism did. ${ }^{32}$

If secularism is meant to protect diversity, then how do we define religion so that no belief is left behind? Taylor and Maclure argue in favour of a conception of freedom of religion that is radically subjective. ${ }^{33}$ In order to know what counts as religion one has to look at individual conscience. Each individual will be able to express its claim of conscience in a way that captures its depth and vulnerability. Religion is collapsed into the wider category of conscience. But by collapsing religion into conscience, Taylor puts at the center of its political doctrine a Christian protestant bias in favour of individualistic forms of religion based on conscientious claims. ${ }^{34}$ Thus, Taylor's subjective definition of religion does not fully escape the problem of the Christian bias.

If religion is radically subjective, then religious claims are likely to multiply. How does Taylor's account deal with them? Taylor's secularism deals with diversity by searching for equilibrium between the French trinity of values: liberty, equality and fraternity. ${ }^{35}$ In this context, liberty means that no religious view should be coerced to change or adopt different beliefs. Equality means that all religious and metaphysical views should be treated equally and none should be privileged. Fraternity means that

\footnotetext{
31 Ibid., 61.

32 Ibid., 59.

${ }^{33}$ J. Maclure and C. Taylor, Secularism and Freedom of Conscience, HUP (2011).

${ }^{34}$ For a similar point, see Cecile Laborde, "Protecting freedom of religion in the secular age," the Immanent Frame, available at http://blogs.ssrc.org/tif/2012/04/23/protecting-freedom-of-religion-inthe-secular-age/

35 Charles Taylor, 'How to define Secularism,' in Alfred Stepan and Charles Taylor (eds), Boundaries of Toleration, Columbia University Press (2014), 61.
} 
all views should be heard in matters of the constitution of society as well as on its policies to obtain the desired goals. The fundamental rethinking of secularism requires from the state a neutral position that relies on overlapping consensus as far as the general fundamentals are concerned, but with no pre-conception as to how the fundamentals will be balanced one with another. The trinity of values will bring inevitable conflicts, and will result in a set of dilemmas, which our societies are bound to face. To cope with such dilemmas, the secular state cannot adopt one size fits all solution, but should be patiently engaged in the negotiation of a collective identity that can only be done trough the good faith attempt to always secure the three or four goals mentioned above.

We can single out from Taylor's account two competing understanding of secularism. The former is historical secularism, a project shaped in the dark ages of church and state conflict. The latter is a positive, substantive, secularism that attempts to respond to the present age of diversity at the metaphysical and political level. Taylor believes that the context in which secularism has been formulated has changed beyond recognition, and it is now time to re-formulate the content of that concept in light of the profound changes of context. ${ }^{36}$

I agree with that distinction: political and ethical secularism agree so far. It is high time to rethink secularism, and even to rescue it from its own negative reputation. It is not about religion any longer. But the two secular accounts part company over the concept of conscience. Is it possible to be neutral, if we start our analysis of freedom of religion from a concept such as conscience? The idea of conscience has a clear western root, and more precisely it has an obvious Christian connotation, and its interpretation divides protestant and Catholic Christianity. ${ }^{37}$ Can such a notion be the starting point of a neutral evaluation of freedom of religion? Instead of focusing on conscience as a source of moral knowledge and moral action as Taylor does, I focus instead on thought, and suggest that religious belief is an expression of diversity of thought.

\footnotetext{
${ }^{36}$ Charles Taylor, 'How to define Secularism,' in Alfred Stepan and Charles Taylor (eds), Boundaries of Toleration, Columbia University Press (2014), 63.

37 Richard Sorabji, Moral Conscience through the Ages. Fifth Century BCE to the Present, OUP (2014).
} 
The second point of disagreement concerns the French trilogy of values. By suggesting that the French trilogy provides the content for secularism, Taylor does not address the problem of what to do when secular dilemmas arise. Secularism, to have a bite, should be able to give guidance as to the management of secular dilemmas that will have to be dealt with by political actors and judges. What can be done in those cases? What kind of compromises can be found if secular dilemmas are genuine? Taylor defends neutrality as a desirable regulative principle. Even if Taylor is cautious as to how the balance can be achieved, he nevertheless leaves ample powers to secular institutions to come up with a good faith balance of those values. But what does it mean to balance competing values in a way that preserve them all? This of course the central question, but Taylor does not really provide a method to answer it. So it is not clear what would qualify as a good faith attempt to balance competing values.

Taylor's new conception of secularism is more inclusive than negative secularism, but it is not immediately clear where its values originate. The French trinity constitutes a venerable wish list, but it is more of a stipulation than the realization that those values are constitutive of secularism. Taylor's secularism wants to present itself as a practical response to the problem of managing diversity. It does not aim to replace the gap left by the waning away of the comprehensive religious view, as pointed out in Taylor's A Secular Age. There is a hiatus between Taylor's genealogical explanation of the move towards a secular age, and Taylor's pragmatic secularism defended in the context of Canadian politics. ${ }^{38}$ In fact, Taylor's political secularism runs the risk of simply upholding traditional Christian views in the garb of secular values. ${ }^{39}$ This is the case in particular when he defends freedom of conscience as the central tenet of any conception of religious freedom. ${ }^{40}$ Conscience is hardly a universal concept that

\footnotetext{
38 J. Maclure and C. Taylor, Secularism and Freedom of Conscience, HUP (2011).

39 The false assumption is that there is a sharp distinction between secular values and religious values. Secular values have been shaped and defined in relation to religious ones: thus 'secular' is often a negative property of that which is not religious. But then again, this implies that there is a stable definition of what qualifies a religious argument as well as a clear method to strip an argument from its religious garb. I find this disingenuous. Take for example, the principle of sanctity of life. It is used by religious and non-religious people in countless arguments on euthanasia, abortion etc...but who exactly holds the copyright to the understanding of sanctity of life, given that it is a religious idea to begin with?

40 J. Maclure and C. Taylor, Secularism and Freedom of Conscience, HUP (2011).
} 
includes all forms of religious diversity. It is rather a Janus faced concept that has religious and secular facets.

To conclude, there are two main problems with Taylor's political secularism. Firstly, it defines religion by collapsing it into conscience. This move seems to be neutral and impartial but it is not. Conscience is the expression of a Christian protestant understanding of what religion should amount to, namely a private engagement with the divine that is not mediated by social institutions. Secondly, it acknowledges the existence of deep secular dilemmas, but does not offer a convincing way of dealing with them; to suggest that good faith attempt to balance competing values might be enough to deal with secular dilemmas does not take those dilemmas seriously. In order to cope with secular dilemmas we have to recognize that secularism is an ethical doctrine that defends the superiority of diversity over homogeneity; religious worldviews are but one expression of diversity and they can be protected as such but not more than that nor less. The idea is not to work towards an overlapping consensus, but to defend the necessary primacy of ethical secularism.

\section{b. Ethical Secularism}

Ethical Secularism takes secular dilemmas seriously. To suggest that it is possible to reach a compromise, as political secularism does, amounts to a denial of dilemmas, and to the silent entrenchment of the majority's views on the place of religion in the public sphere. The fact that we face secular dilemmas must be taken as a sign of vitality of the political society. The conflict between the majority and the minorities of a society should not be swept under the carpet. It must be acknowledged and dealt with in a way that promotes a genuine exchange.

Ethical secularism makes a non-neutral choice in favour of diversity and against homogeneity. Diversity works as an interpretive device of all other values: whenever a conflict between values is at stake, diversity works as a tiebreaker. Take for example the crucifix case: does its presence contribute to a more diverse environment or does it promote homogeneity? Diversity clearly militates against the presence of the crucifix. Diversity of worldviews is superior over homogeneity, which has been the European default position after the Treaty of Westphalia. After all, the very 
homogeneity that characterized Europe after the Peace Treaty of Westphalia was an explicitly value-laden political decision taken at the international level in order to put an end to religious wars. ${ }^{41}$ It is time to replace homogeneity with diversity as a nonneutral choice. The compromise entrenched by the Treaty of Westphalia can be rejected: we reject the idea that we have to carve out religiously homogeneous nation states out of a broader European political space. To be sure, Westphalia engineered homogeneity to cope with religious conflicts. An evil was certainly removed, but with it, the Westphalian political arrangement also removed the richness of socio-cultural and religious diversity. Postwar Europe regained very quickly a robust degree of diversity, and that contributes to a richer and more interesting environment; it is also a non-artificial environment. To be sure, it also contributes to a challenging political situation and the task of the secular state is to deal with diversity in a way that preserves its contribution and limits its risk. Ethical secularism has a strong instrumental component and a thin epistemological commitment. ${ }^{42}$ It is instrumental in the sense that it is the value with which European states can be nudged away from state homogeneity. It has a thin epistemological commitment in the sense that diversity does not stand for a fully-fledged substantive commitment. It simply challenges received ideas and works as a comprehensive worldview of worldviews, enabling rather than silencing them.

It is necessary to move towards an affirmation of the secular age, something that Taylor is not prepared to do. Ethical secularism displays no nostalgia for our religious past: the secular age is presented as being superior over the prior religious age. As an illustration of the superiority we can take freedom of religion: religious freedom can only be realized in a secular framework where all religious and non-religious views can live and thrive one next to another. To do so, there must be at least a minimum core of unity that is common to all religious and non-religious people alike. Since religious ethical views cannot comprehend other views -because by definition one religious truth excludes other religious truths- we have to look for a secular view that promotes diversity. Religious freedom is not protected where one religion is the only one that dictates the rules of the game for everyone.

\footnotetext{
${ }^{41}$ Lorenzo Zucca, A Secular Europe. Law and Religion in the European Constitutional Landscape, Oxford: OUP, (2012).

${ }^{42}$ David Enoch, Political Philosophy and Epistemology, unpublished manuscript in file with the author.
} 
The secular age is affirmed at three different levels. At the political level, ethical secularism is affirmed as the limitation of the authority of the state in matters of religious and non-religious diversity. In this sense, ethical secularism makes ample room for freedom of religion. At the moral level, it is a vision of how to live together that promotes genuine respect of religious and non-religious diversity. At the metaphysical level, it holds that diversity amounts to free thought. Thought is free when it is able to question itself constantly, but it is not necessarily presuppositionless: it cannot be reduced to pure logic. Any thought starts from an assumption, and then goes on examining it under the light of reason. Unconstrained thought can both be religious or non-religious. Free thought is the ultimate and most basic element of ethical secularism; in turn, this profoundly changes the conception of religion we are working with.

Ethical secularism is ultimately severed from any conventional understanding of religion since it regards religion as one particular expression of free thought. Free thought is compatible with the idea of starting from a set of assumptions. The fact that religion begins with an assumption about faith, singles it out as a special form of thought that is different from other forms of thought that postulate natural reason as the sole guiding light. Religious and non-religious thought are equally protected and equally open to further inquiry. Of course, beliefs will be open to challenge and when they will not be able to withstand those challenges, they will not be able to form the basis of any policy decision. Ethical secularism is positive in that it is not defined against religion, but it is instead an affirmation of diversity of thought. Religion as a result is not central to the definition of ethical secularism. Religion is one of the worldviews protected by it. Ethical secularism promotes a genuine exchange about all basic values and practices in our societies. The exchange does not require shedding one's own assumptions, but it does ask every participant to bring those assumptions to the forefront and to be prepared to accept all the challenges that free thought can bring to various ethical views of religious and non-religious origin.

It is a mistake to think that diversity of thought calls for legal pluralism. It is also a mistake to think that value pluralism is associated in any meaningful way with legal pluralism. Diversity of thought can be best realized within a unitary political 
framework. Human beings set up political institutions to maintain a certain degree of stability despite human irrationality due to the natural primacy of emotional reactions. Human beings come together and form political communities as a matter of necessity: they know that to form bonds is much more likely to serve their interest in survival and it is also likely to accrue one's own control over the external world. Political institutions are thus created to protect those basic human interests and as long as they are capable of serving those interests, they protect their existence; if political institutions start behaving in a way that undermines those basic human interests, then they become exposed to failure and ultimately to extinction.

Political institutions can develop an instrument to deal with religious diversity: I call that instrument the marketplace of religions, which is a sub-system of the marketplace of ideas. ${ }^{43}$ The link between the ethical and the instrumental is not straightforward, so a few clarifications are in order: firstly, the connection is not direct; human beings have no access to the full knowledge of their biases; they only have a very fragmentary knowledge of human nature and of its own causal laws. Secondly, the impossibility of knowledge of human nature points to the inherent limits of human rationality that can at best work under less-than-ideal conditions of limited knowledge. Thirdly, limited rationality means that human beings are reaching practical decision on the basis of emotional reactions to the natural world. This means that prescriptive human laws have to engage with psychological motivations and provide appropriate answers to them. Fourthly, the success of a rule-maker will be measured by its ability to grasp the overarching interest of the community, while at the same time motivating people to strive together in that direction.

From an epistemological perspective, secular political institutions can hardly be bound by the idea of an overlapping consensus amongst reasonable people. That is presupposing too much about our possibility to know where the consensus lies and our ability to maintain it despite inevitable conflicts of worldviews. If it is correct that the actual possibility of consensus on religious matters amongst reasonable people is out of reach, the commitment to neutrality put forward by political secularism

\footnotetext{
${ }^{43}$ See chapter 5 in L. Zucca, A Secular Europe. Law and Religion in the European Constitutional Landscape, OUP (2012).
} 
becomes problematic; ${ }^{44}$ neutrality assumes that the secular state is completely separate and detached from any religion. But that is obviously not the case, and the existence of the double standard highlighted before shows the extent to which that is not true. The existence of inbuilt double standard makes neutrality impracticable and secularism weak. Neutrality is impracticable because European states automatically give preference to their own traditions that are inevitably rooted in one form of Christianity. Secularism is weak because it depends on its relation with one dominant religion. Neutrality could only make sense if biases could be completely removed. But this is unlikely to happen. And even if it could happen, until this has not materialized, it is necessary to suspend the talk of neutrality and start with the work on the removal of biases. The marketplace of religions removes biases by giving more space to all religions, while subordinating all religions to the paramount requirements of free thought.

The marketplace of religions has the following features: first of all, the state is not neutral towards religions. Historically, it treats some religions with great regards and distributes specific benefits and burdens; to improve on that record, the secular state has to eliminate the barriers of access to the marketplace of religions. So for example, a state with an established religion is likely to be creating undue burdens to other religions; it therefore has to improve its relations with non-established religions. It is important to understand that the marketplace of religions does not depend on the separation between religion and state. On the contrary, the marketplace of religions is there to organize collaboration between the state and religions. Collaboration does not require neutrality: the secular state collaborates with all the religions that offer goods and services for the society. In exchange for those goods and services, the secular state may grant some privileges to religions as long as they accept to exercise those privileges in accordance with the ordinary laws of the state. If a religious institution accepts a privilege, such as a tax break, it accepts to act as a provider of public services and cannot be exempted in any manner from the regular application of the law.

The marketplace of religions is a sub-category of the marketplace of ideas. To this

${ }^{44}$ Both Rawls and Taylor insist that liberal neutrality should be understood against the background of the overlapping consensus. 
extent, it recognizes a place of religion in the public sphere as an expression of an idea; if the idea conflicts with basic values of a liberal democratic society, then religion has an explanatory burden to overcome if the idea claims to be the basis of behavior that is not compatible with ordinary law. In this way, religions open themselves up to rational scrutiny of their ideas and accept robust exchange between religious and non-religious people. Freedom of religion is protected as a form of free thought. Its protection is lowered when free thought turns into expression and action. The marketplace is the instrument through which the secular state can make sure that no religion curtails other freedoms or engages in discrimination.

To move from religious conflicts to peace and stability, one has to have a double account. On one hand, ethical secularism affirms the superiority of diversity over homogeneity. On the other, it offers an instrument -the marketplace of religions - that treat religions as part of the unofficial public sphere ${ }^{45}$ and as partners of the state while at the same time subjecting them to constraints of freedom and equality that apply to all other public actors.

\section{c. Cashing out Ethical Secularism}

Ethical secularism does not ask states to show neutrality at the political level; instead it promotes one comprehensive view that prioritizes diversity over homogeneity. Ethical secularism requires the rethinking of political identity in light of the change of social identity. For example, Italy's social homogeneity along catholic lines is no longer true; as a consequence Italy's political identity should also be re-thought: it must become a secular state that caters for all its religious and non-religious citizens.. In other words, Italy in particular and Europe more generally must become Italy can be further criticized from the viewpoint of ethical secularism. A society with a very homogeneous population and a strict relation between Church and State can hardly make space for genuine diversity of worldviews. In such a context, ethical secularism, with its instrumental marketplace of religions, is going to have a deeper impact because it has to assist a mono-religious society move towards a religiously plural

\footnotetext{
${ }^{45}$ See J. Habermas, The Structural Transformation of the Public Sphere. An Inquiry into a category of Bourgeois Society, The MIT Press (1991). See more specifically, Jurgen Habermas, 'Religion in the Public Sphere', 1 European Journal of Philosophy (2006) 1-25.
} 
one. ${ }^{46}$ self-consciously secular, rather than being secular by default. Europe needs to examine its psychological biases before turning to regulation and limitation of freedom and equality. France, for example, erred very badly when it presented the prohibition of burquas on public streets as a defense of freedom and equality. It is neither. Moreover, it entrenches a psychological bias against Muslim minorities.

The stakes are very high. In order to remove one's own psychological biases, one needs external help. The ECtHR can provide some help by bringing the national state to reconsider its own biases in a dialogic manner. Judicial institutions in Europe are the place where a discussion of that kind can begin. For the moment, unfortunately, the ECtHR is simply re-enforcing the status quo. Lautsi v Italy and SAS v France illustrate the problem of inbuilt biases and double standards. Majority religious symbols (the cross) are taken for granted. Minority religious symbols are contested everywhere, including when someone would like to display them privately. It is therefore not enough to ask the state to be neutral politically or legally, if it works on the basis of assumptions according to which Christian symbols are passive, while Islamic symbols are threatening. ${ }^{47}$ Those assumptions cannot withstand robust scrutiny. Until the biases have been unraveled, there is no change to make neutrality work in any meaningful way. To unravel biases, it requires a systematic evaluation of one's political commitments. The existence of biases is incompatible with any talk of legal or political neutrality.

What can the ECtHR do then? The first step is to help nation states to unravel their own biases. The second step is to help to create instances of genuine re-thinking about one's own identity. If a nation's identity happens to be biased towards one religious identity, then these legal cases are the best starting point for a genuine exchange. I confess to have in-built biases myself. I have never felt the presence of the crucifix in the classroom. It was literally as any other piece of furniture: that was the point of the fascist decree that still defines what a classroom should look like. In 1929, when the decree was taken, it was not even a matter for discussion. Courts, classrooms,

\footnotetext{
${ }^{46}$ For a similar point see Nadia Urbinati, "The context of secularism: A Critical appraisal of the PostSecular Argument," in Susanna Mancini and Michel Rosenfeld (eds), Constitutional Secularism in an Age of Religious Revival, Oxford: OUP (2014), p.15.

${ }^{47}$ Lorenzo Zucca, 'A Comment to the Grand Chamber decision', 11 International Journal of Constitutional Law, 218-229.
} 
administrations would display a crucifix. Who was there to object? The Italian society was still religious and homogeneous. Today, Italy's homogeneity is waning, but there is no sign of a rethinking of the unilateral privileged relation between Church and State. ${ }^{48}$ It is also less religious, and in any case the post-war constitution introduces the notion of secularity of the state, that is to say that at least in principle the Constitution entrenches legal secularism as a fundamental tenet. The ECtHR could have helped Italy to reflect on the implications of its changing socio-cultural context as well as on its commitment to legal secularism.

Italy has to respond to the changes of its society in order to remove the barriers that make co-existence between religious and non-religious people possible. The state has to engage in a serious and thoughtful debate about its identity and the symbols connected with them. The crucifix saga was the perfect moment to engage in such a debate: is Italy laic or is it religious? And more importantly, if it is laic as the Constitutional Court maintains, what does that imply? Ethical secularism as I defend it requires the state to be active and not merely neutral. Being active means first and foremost to engage in the debate wholeheartedly, which Italy has not done. Being active also means to come up with an official position that explains the principles of the state, as well as the decisions that flow from those principles. Italy has not done that; it simply reacted against change. It did not explain to people its position.

The ECtHR had the chance to ask Italy to be a grown up and mature state; a state that treats the people as citizens, and not as children. But it did not do it. So the result is that Italy lives with the paradox of being constitutionally laic, while supporting Christian symbols. Here lies the problem of modern Europe: it is not serious about digging up the in-built biases that will result in more discrimination towards nonChristian symbols and practices. To do so is to put one's head in the sand and avoid talking about one's psychological problems of intolerance and hatred towards immigrants of different cultural and religious background. The inability to tackle those emotions results in the success of populism, which by definition gains political advantage by rousing negative emotions.

\footnotetext{
${ }^{48}$ Nadia Urbinati, note 46, pp. 17-18.
} 
Populism is rife in France. When France banned the full-face veil, it was clear more than in any other case that the state was acting on a populist basis. ${ }^{49}$ It was encapsulating in legislation the fears of French people towards Islam. ${ }^{50}$ The legislation is purely symbolic and has limited effect on individual behavior: it only concerns two thousand women out of a Muslim population of over four million people. ${ }^{51}$ France is sending a message to the French electors and to the rest of Europe. The actual behavior of people is not important: those women that wear the veil are typically doing so for highly personal motives, and the full-face veil is not even supported by the French Muslim community. By limiting freedom of expression and freedom of religion of few women who want to wear a controversial dress, France gives up on its secular commitments rather than upholding them. Even worse, France embraces a populist attitude and transforms it into national legislation. The risk of populism is always present if the political representatives are allowed to play with the negative fears and biases of the country at large.

A deeper issue surfaces here, and it is what European political leaders are failing to grasp: what happened in Paris with Charlie Hebdo is not only about religion. It is first and foremost about alienation of people not belonging to the mainstream society. Politicians right and left would like to isolate the threat of extremist religion or at best circumscribe it. ${ }^{52}$ They believe that one part of Islam leads to violent extremism, but completely fail to examine what are the responsibilities of national states. France and the UK have been failing their people in numerous different ways. They entrenched harsh economic inequalities throughout the society and they pursued illiberal policies trampling individual rights and privacy. The rise of extremism is a symptom of the crisis of the state. ${ }^{53}$

\footnotetext{
${ }^{49}$ Patrick Weil, 'Headscarf v. Burqa: Two French bans with different meanings', in Susanna Mancini and Michel Rosenfeld (eds), Constitutional Secularism in an Age of Religious Revival, Oxford: OUP, (2015).

50 For a masterful fictional account, see Michel Houellebecq, Soumission (2014).

51 Eva Brems, 'The experience of face veil wearers in Europe and the law,' in Eva Brems (ed.), Diversity and European Human Rights. Rewriting Judgements of the ECHR, CUP, (2015). ${ }^{52}$ David Cameron's speech on religious extremism in Birmingham delivered on the $20^{\text {th }}$ of July 2015 , available here: http://www.independent.co.uk/news/uk/politics/david-cameronextremism-speech-read-the-transcript-in-full-10401948.html ${ }^{53}$ Lorenzo Zucca, 'The Crisis of the Secular State: A reply to Prof. Sajo,' 7 International Journal of Constitutional Law, 494-514
} 
Alienation of young individuals go hand in hand with a loss of faith in liberal democracies: it is also about the status of immigrants in a society that is not capable of offering opportunities to disenfranchised individuals. ${ }^{54}$ Many have failed to notice what should be obvious. The first people to pay the price for economic decadence are the minorities in a society. Strong religion steps in at this point: when an individual is looking for answers that the state, and the society, are not providing the answers that individuals are seeking.

Ethical secularism asks national states to be conscious of what kind of paths lead to radicalization. Schools, workplaces, and social media: alienation and estrangement from the mainstream society happen there; the state should be aware of it. When individuals are alienated, they resort to strong religion as a way to respond to their malaise. Either before they commit a crime or once they enter prison. ${ }^{55}$ Sometimes it may help them, but often it may radicalize them.

The ECtHR has no power to tackle systematic biases arising from substantive inequalities, but it can ask national states to reflect on their shortcomings. Indeed, ethical secularism asks European institutions to address the underlining causes of religious strife, and does not simply offer a quick solution to discrete religious conflicts. The ECtHR has a responsibility that it cannot renounce: it must bring nation states to reflect about its own policies that entrench a double standard between the majority and the minority. When France excluded young Muslim girls from French public schools for wearing the veil, France contributed to disenfranchisement. ${ }^{56}$ French public education is an instrument with which individuals are trained to become citizens of the republic. They cannot be expected to be citizens prior to entering school. Living together is a practice that can be facilitated by the state in major social institutions, such as schools. Living together cannot be used as a reason to criminalize the behavior of people who are alienated from the society. The ECtHR

\footnotetext{
54 See for example Obama's take on the European situation: http://foreignpolicy.com/2015/01/16/obama-slaps-europe-for-failing-to-integrate-muslims/

55 Gabriele Marranci, Faith, Ideology and Fear: Muslim Identities Within and Beyond Prisons, Continuum Religious Studies (2009).

56 See for a full account of more than twenty years of debates, Cecile Laborde, Critical Republicanism and the Hijab, OUP, (2011).
} 
should not have accepted such a lame justification on the part of France. It should have challenged it and asked France to reconsider it.

\section{Conclusion}

Europe needs to rethink secularism. It is often assumed that Europe is already secular, but that needs to be reassessed. I tried to show that Europe is committed to negative secularism, which is the product of past struggles, but not in touch with the present. Negative secularism thrives because of the existence of an enemy: fundamentalist religion. In this struggle, Europe has everything to lose. Negative secularism empowers the most aggressive religious minorities by putting them in the position of martyrs. Repression of religion provokes a strong backlash, and alienates moderate religious people. Europe's long secular and religious heritage needs to be pulled apart and re-imagined.

This paper suggested that ethical secularism should be at the center of a European secular manifesto. Ethical secularism's central message is that diversity is superior over homogeneity. In order to thrive diversity of all kinds requires a stable unitary framework, the marketplace of religions. Ethical secularism is an affirmation of the secular age, rather than a negation of religion. Ethical secularism attempts to free itself from in-built biases against religious minorities to become a fully independent worldview of worldviews. The illustration used in this paper is the negative attitude towards European Muslims and towards Islam more generally. It is hard to deny that the European Court of Human Rights, for example, treats Islamic symbols and practices in a discriminatory fashion even if it starts with the recognition of freedom of religion for all.

European courts will be successful if they address inbuilt biases that make religious minorities aliens in a society, while entrenching the beliefs and symbols of religious majorities. Living together means to develop an ethical secular framework within which all political and religious ideologies can find their place. What if those ideologies clash? Clashes are part and parcel of dynamic societies. The burden of ethical secularism is to remove buried assumptions from the table that only lull us into believing that liberal institutions can find compromises at little cost. It will thus make 
Rough draft, please do not circulate or cite

sure that clashes can be channeled into moments of genuine exchange, which include actual debate about the place of the crucifix in the classroom or the prohibition of the full-face veil in the streets. Genuine exchange will not produce agreement. Lines will have to be drawn. But I suggested that lines drawn from a position of genuine openness, coupled with a clear instrumental framework such as the marketplace of religions, will be preferable over lines drawn from a position of in-built biases and illusions about overlapping consensus.

Secularism is being questioned in Europe, but the question is not whether or not we want secularism; rather it is about which conception of secularism we want. The question we have to ask is: what do we want Europe to be like? Do we want it to be a racist place that discriminates those people that do not fit the rather narrow profile shaped by the European Christian past? Or do we want it to be an open place that is confident about its secularism and its achievements and for that reason it can afford a great amount of genuine diversity without falling apart? I opt for the second. 